Emir. J. Agric. Sci. (1993), 5 : 125-143

\title{
Meat Characteristics of Sheep and Goat Breeds Commonly Consumed in U.A.E. 1. Carcass Characteristics.
}

\author{
A.A. Nigm, O.M. Abdallah, M.B. Aboul-Ela, Z. Sewar A1- \\ Zahab and A.M. Soliman
}

Faculty of Agricultural Sciences, U.A.E. University, P.O.Box 17555, Al-Ain, U.A.E.

\section{ABSTRACT :}

This study was conducted at Al-Ain Automatic Slaughter House and the laboratory of Faculty of Agricultural Sciences, U.A.E University during the period from November 15, 1989 through June 15, 1990. The study aims at investigating the influences of breed and age of animal on dressing percentage and physical and chemical composition of some sheep and goat breeds commonly consumed in U.A.E.

Age of animal exerted significant effect $(\mathrm{p}<.01)$ on body weight (BW), hot carcass weight (HCW) and dressing percentage (DP) measured on 73 Merino sheep. Least squares means obtained for these traits were $40.5 \mathrm{~kg}, 20.7 \mathrm{~kg}$ and 49.8 $\%$, resp. Corresponding means obtained for 44 Somali goats were $23.3 \mathrm{~kg}, 10.9 \mathrm{~kg}$ and $46.6 \%$, resp. The effect of age, however, was significant only on HCW and DP $(\mathrm{p}<.01)$.

Physical dissection of 56 samples representing 9-10-11 ribs cut showed that Turkish lambs had more bone than had Merino ones $(\mathrm{p}<.05)$. Age of sheep had significant $(\mathrm{p}<.01)$ effect on percentages of lean, fat and bone and on fat thickness over the rib cut. Means obtained for lambs vs. mutton in the four above mentioned traits were 46.3 vs. $38 \%$; 30.6 vs. $45 \%$; 23.1 vs. $16.9 \%$ and 2.61 vs. $5.95 \mathrm{~mm}$., in respective order.

Chemical analysis of the 56 Longissiums dorsi muscles of the above mentioned rib cuts showed that Merino lambs had significantly more protein $\%$ while Turkish showed 
higher $\%$ fat $(p<.01)$. The Merino also had greater $\%$ of NFE (0.56 vs. $0.17, p<.05)$. Age showed significant effects on $\%$ ether extract and \% ash $(\mathrm{p}<.01)$ and on $\%$ NFE $(\mathrm{p}<.05)$. Mutton had markedly greater fat \% (4.94 vs. 1.92$)$ while lambs showed relatively higher estimates for NFE and ash percentages.

Simple, within subclass, coefficients of correlation revealed the existence of significant relationships among different physical and chemical parameters used in this study.

Key words : Breed, Carcass characteristics, Goat, Sheep, U.A.E.

\section{INTRODUCTION}

United Arab Emirates imports about $80 \%$ of population's consumption from red meats. Reliable information on the performance of both imported and local breeds of animals are essential for planning effective programmes to improve domestic meat production.

Australian Merino, Turkish sheep and Somali Goats are major breeds commonly consumed in U.A.E. The objectives of the present study were to assess the meat merits of these breeds by estimating their dressing out percentage and their physical and chemical composition. The study aimed also at analyzing the effects of animals breed and age on the physical and chemical composition of their carcasses. Relationships among different physical and chemical components were also investigated. 


\section{MATERIALS AND METHODS}

The study was conducted at Al-Ain slaughter house and at the labs of Animal Production Department, U.A.E. University, Al-Ain, U.A.E. The study started on November 15, 1989 and terminated on June 10,1990 .

\section{Dressing Percentage (DP) :}

To estimate dressing out percentage (DP), 73 Australian Merino male and 44 male Somali goats were chosen at random from animals imported for slaughter. Body weight (BW) was recorded to the nearest $\mathrm{Kg}$; and after animals were slaughtered and dressed, hot carcass weight (HCW) and total weight of head, hide and four legs was also recorded. Cold carcass weight (CCW) including kidneys was determined after carcasses were chilled for 24 hours. DP was estimated as \% CCW from BW. Data were analyzed using SAS General Linear Models procedure, for each genotype (Merino and Somali), separately, using the following model :

$$
Y_{i j}=u+a_{i}+e_{i j}
$$

where : $\mathrm{Y}_{\mathrm{ij}}$ represents $\mathrm{BW}, \mathrm{HCW}$ or DP; $\mathrm{u}=$ overall mean; $\mathrm{a}=$ the effect of age, estimated by teething of the $\mathrm{i}$ th animal, $\mathrm{i}=5$ (for Merino) where $1=<1.5,2=1.5-<2,3=2-<3,4=3-<4$ and $5>4$ years while for Somali, $\mathrm{i}=3$ where $1<2, \quad 2=2-<3$ and $3>3$ years; and $\mathrm{e}_{\mathrm{ij}}=$ common random error. 


\section{Physical dissection of rib cut :}

Rib cut of the 9th, 10th and 11th ribs was physically dissected into lean, fat and bone to predict carcass composition. Sampling included carcasses of 30 Merino lambs, 15 Merino sheep and 11 Turkish lambs. Data were analyzed to investigate the effect of breed of lamb (Merino vs. Turkish) and the effect of age of Merino sheep (lambs vs. mutton) on percentage of lean, fat and bone in rib cut. Carcasses of Somali goats are not easy to get from the market because they are commonly slaughtered by individuals not butchers.

\section{Chemical Composition of Longissimus Dorsi} Muscle :

Longissiums dorsi muscle of the above mentioned 56 rib cuts were used to determine its chemical composition according to AOAC (1986). Data were analyzed to investigate the effect of breed of lamb (Merino vs. Turkish) and the effect of age of Merino sheep (lambs vs. mutton) on levels of protein, ether extract (fat), nitrogen free extract (NFE) and ash content.

\section{RESULTS AND DISCUSSION}

\section{Dressing percentage (DP) :}

Table 1 shows means of body weight (BW), hot carcass weight (HCW) and dressing percentage (DP) of Merino sheep. All traits were significantly affected by age of animal $(\mathrm{p}>01)$. BW and $\mathrm{HCW}$ increased with advancement of age; DP declined in age group 2 and 
Table 1. The effect of age on body weight, hot carcass weight and dressing percentage (DP) of Merino sheep imported for slaughter in U.A.E.

\begin{tabular}{|c|c|c|c|c|}
\hline Class & $\mathrm{N}$ & $\begin{array}{l}\text { Body weight } \\
\text { (BW, kg) }\end{array}$ & $\begin{array}{l}\text { Hot carcass } \\
(\mathrm{HCW}, \mathrm{kg})\end{array}$ & $\begin{array}{c}\mathrm{DP} \\
(\% \mathrm{CCW} / \mathrm{BW}\end{array}$ \\
\hline Overall & 73 & $40.5 \pm 1.06$ & $20.7 \pm 0.61$ & $49.8 \pm 0.52$ \\
\hline \multicolumn{5}{|l|}{ Age group : } \\
\hline $1=<1.5 \mathrm{yrs}$ & 11 & $29.0 \pm 1.91$ & $14.3 \pm 1.01$ & $48.3 \pm 1.12$ \\
\hline $2=1.5-<2$ & 10 & $34.9 \pm 2.00$ & $16.9 \pm 1.06$ & $46.9 \pm 1.18$ \\
\hline $3=2-<3$ & 16 & $38.6 \pm 1.58$ & $18.9 \pm 0.84$ & $47.5 \pm 0.93$ \\
\hline $4=3-<4$ & 7 & $44.7 \pm 2.39$ & $21.9 \pm 1.27$ & $49.0 \pm 1.40$ \\
\hline $5=>4 \mathrm{yrs}$ & 29 & $46.9 \pm 1.18$ & $25.1 \pm 0.62$ & $52.8 \pm 0.69$ \\
\hline
\end{tabular}

Source of

Variation :

d.f

Mean

Squares

Age

4

781.6

305.8

113.7

Residual

68

40.1

11.3

13.8

$* * \mathrm{P}<.01$ 
increased gradually thenafter to reach the value $(52.8 \%)$ in group 5. Figure 1 shows the relationship between DP and non-carcass components (head, hide plus the four legs) taken as $\%$ of BW. Thonney et al. (1987) and Butterfield (1988) reported that all noncarcass components are early maturing structures decline progressively, as $\%$ from $\mathrm{BW}$, as $\mathrm{BW}$ increases.

For Somali goats, table 2 shows that age differences in BW were not large enough to catch the level of statistical significance. Means of BW ranged between $22 \mathrm{~kg}$. in age group 1 and $25.1 \mathrm{~kg}$. in group 3. Patti and Restall (1987) found a gradual decline in BW increase of Australian Ferals with advancement of age due to lowered rate of growth. DP averaged 46.6 $\%$ which lies within the range defined by Warmington and Kirton (1990) in their review article on DP in goats (35-53\%). However, Mtenga and Kitaly (1990) reported only $36.1 \%$ as average DP in Tanzanian grazing goats which is a typical East African goat type. DP increased significantly $(\mathrm{p}<.01)$ to $48.5 \%$ in group 2 and declined to 45.3 in group 3, partially due to changes in \% non-carcass components (Figure 2). Devendra and Owen (1983) and McGregor (1982) indicated that DP increases with increasing BW of goats. The age differences obtained here could be of considerable importance if coupled with information on carcass composition and meat quality characteristics.

\section{Physical composition of rib cut :}

Physical dissection of rib cut, fat thickness (FT) over the 9th rib and eye muscle area (EMA) have been widely used for predicting carcass composition 
Table 2. The effect of age on body weight, hot carcass weight and dressing percentage (DP) of Somali goats imported for slaughter in U.A.E.

\begin{tabular}{lcccc}
\hline Class & $\mathrm{N}$ & $\begin{array}{c}\text { Body weight } \\
(\mathrm{BW}, \mathrm{kg})\end{array}$ & $\begin{array}{c}\text { Hot carcass } \\
(\mathrm{HCW}, \mathrm{kg})\end{array}$ & $\begin{array}{c}\mathrm{DP} \\
(\% \mathrm{CCW} / \mathrm{BW})\end{array}$ \\
\hline Overall & 44 & $23.3 \pm 0.62$ & $10.9 \pm 0.19$ & $46.6 \pm 0.85$
\end{tabular}

Age group :

$\begin{array}{lrrrr}1=<2 \text { yrs. } & 11 & 22.0 \pm 1.24 & 9.8 \pm 0.33 & 43.0 \pm 1.57 \\ 2=2-<3 \text { yrs. } & 25 & 23.2 \pm 0.52 & 11.2 \pm 0.22 & 48.5 \pm 1.04 \\ 3=>3 \text { yrs. } & 8 & 25.1 \pm 1.45 & 11.4 \pm 0.39 & 45.3 \pm 1.84\end{array}$

Source of

Variation :

d.f

Mean

Squares

NS

Age

2

22.65

8.34

125.9

Residual

41

16.86

1.21

27.1

$\mathrm{NS}=$ Non-significant. $\quad * * \mathrm{P}<.01$. 


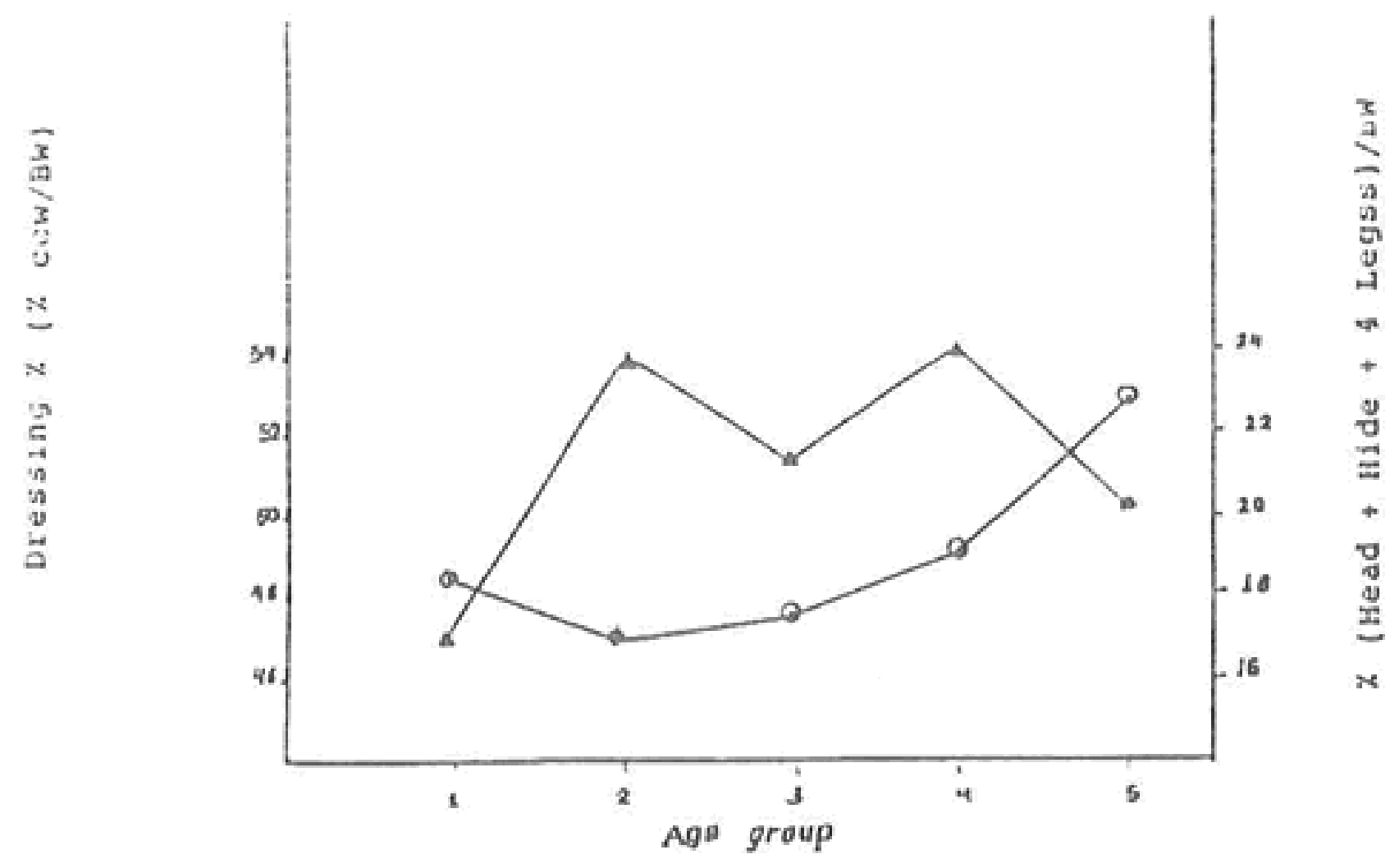

F1g.1Pelationship between dressing percentage (DP) and \%Head+hide+4legs/BW with advance in age of Merino sheep.

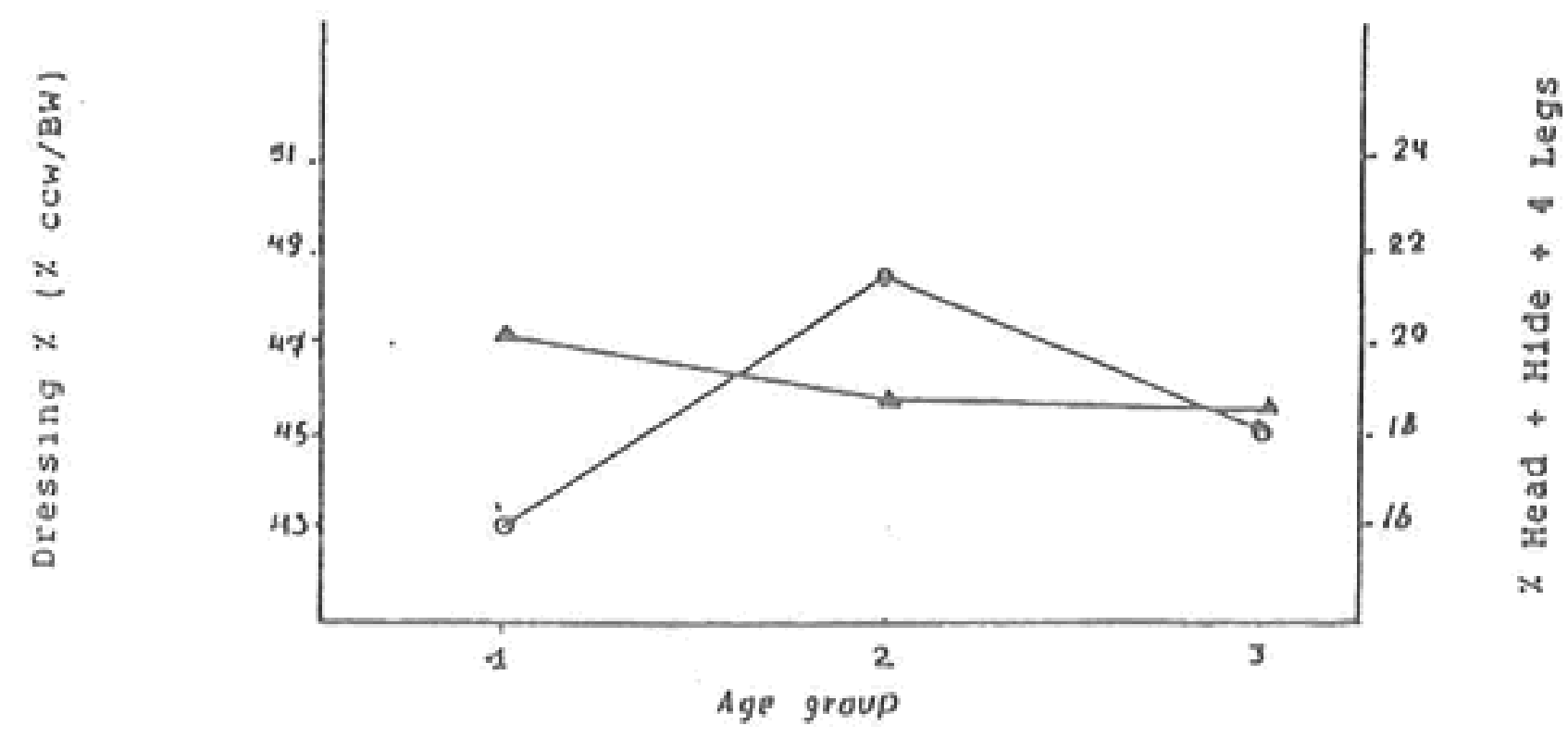

F1g.2Relationship between dressing percentage (DP) and \% Head + hide+4legs/BW with advance in age of Sonali goats. 
(Berg and Butterfield, 1976). Table 3 shows the effect of breed of lamb (Merino vs. Turkish) on the forementioned physical characteristics. The only significant difference existed in $\%$ bone $(\mathrm{p}<.05)$. Turkish lambs showed some 20\% increase in bone \% above the Merino average. The markedly higher $\%$ of fat in Merino ribs compared to Turkish breed (30.6 vs. $24.9 \%$ ) lacks the statistical significance, mainly due to high individual variation.

Age of sheep influenced significantly physical characteristics in Merino (table 4). Lambs had markedly more lean in their rib cuts than had the mutton cuts $(46.3$ vs. $38 \%$, p $<.01)$. Conversely, mutton had about $14 \%$ more fat; 45 vs. $30.5 \%$ for mutton and lambs cuts, respectively. This increase represents almost $50 \%$ of fat content in lambs cuts. This result is elaborated by the difference observed in FT between the two age groups; 5.95 vs. $2.61 \mathrm{~mm} \mathrm{(p>.01)}$ for mutton and lambs, respectively. The mutton had some $6 \%$ less bone which is expected due to the differential rate of growth of bone, muscle and fat with advancement of age (Berg and Butterfield, 1976).

Chemical composition of longissiums dorsi muscle :

Chemical composition is considered more reliable in predicting carcass composition than is physical dissection. Berg and Butterfield (1976) showed that fat depot may, under certain circumstances, carry a large proportion of water and low proportion of chemical fat and hence physical weighing would not detect this effect. The major qualitative change in chemical composition of meat 


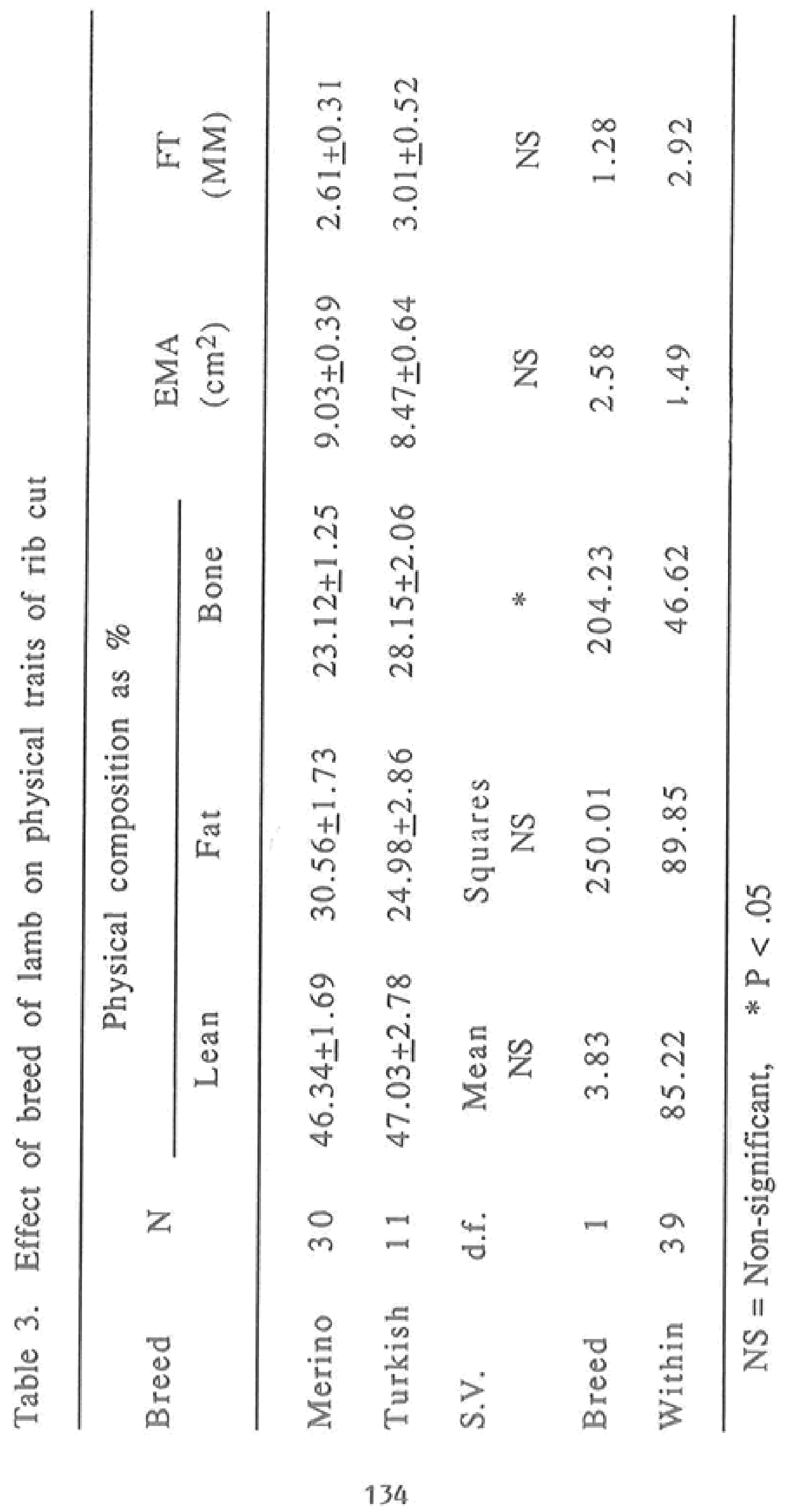




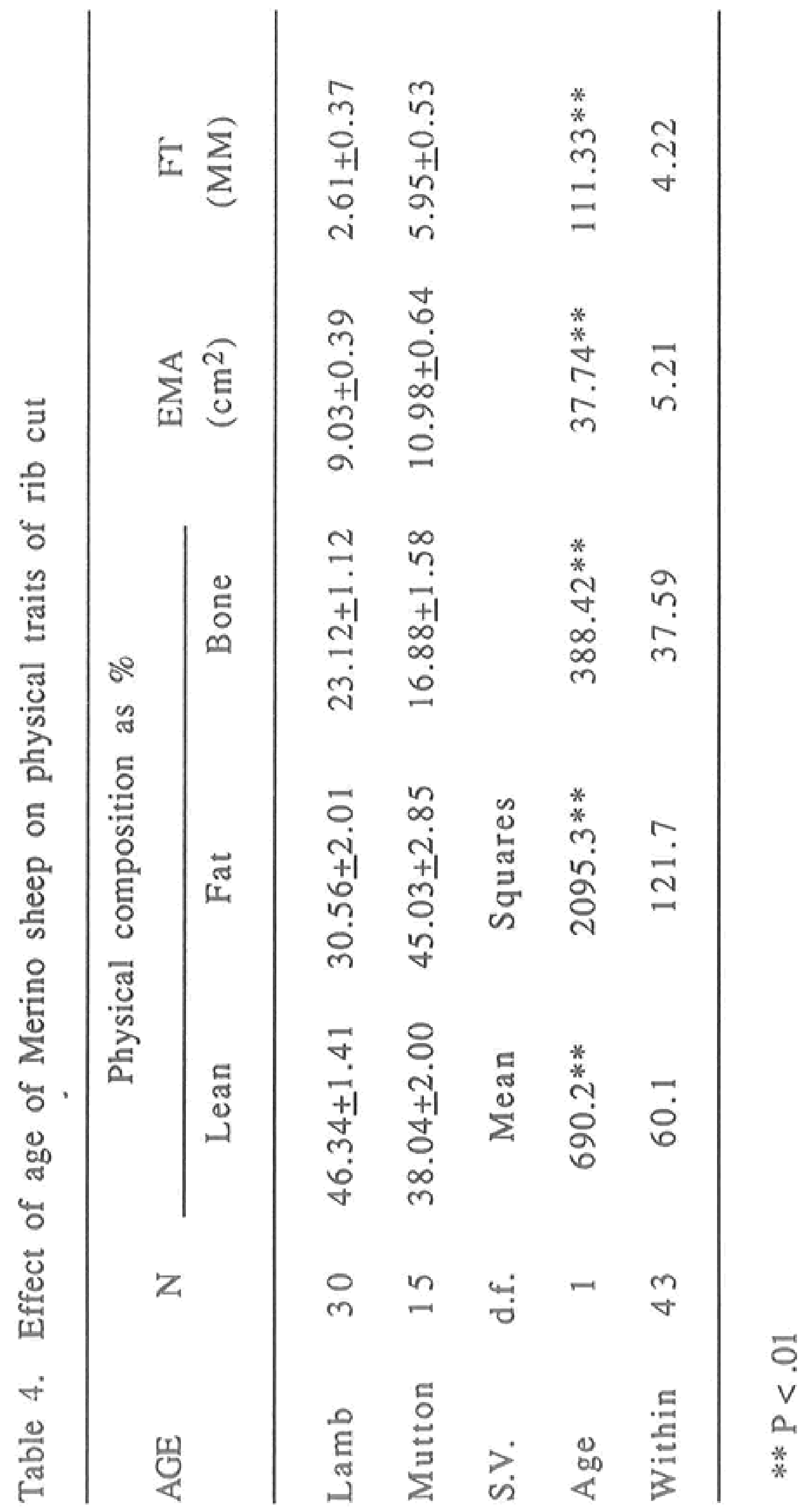


always occur in fat content which in turn influences the other components.

Table 5 presents the effect of breed of lamb on chemical composition of L.d. muscle. The most marked genotypic difference existed in fat percent. Turkish had $1 \%$ more fat which represents an increment of $52 \%$ over the Merino lambs average (1.92\%). The increase in fat content reduced the proportion of protein in Turkish where Merino scored 1.7 more, about $9 \%$ of the Turkish average. These genotypic differences agree with the findings of Berg and Butterfield (1976) that some breeds are early fatteners and others are late.

The effect of age of Merino sheep (lamb vs. mutton) on chemical composition of their L.d. muscles is shown in table 6. Mutton had more dry matter (DM) compared to lambs (26.8 vs. $24.6 \%$, resp.). The major part of this increment is accounted for by the increase in fat content. Mutton had more than double the fat estimated in lamb muscles (4.94 vs. $1.92 \%, \mathrm{p}<.01)$. Conversely, lambs had slightly more protein, the difference, however, was statistically non-significant.

Relationships among physical and chemical parameters :

The relationships, calculated as simple coefficients of correlation within subclasses among the physical components of rib cut and the chemical components of L.d. muscle are shown in table 7. Among the physical components of rib cut, highly significant $(\mathrm{p}<0.001)$ negative coefficients were obtained between $\%$ fat, in one hand, and each of $\%$ 


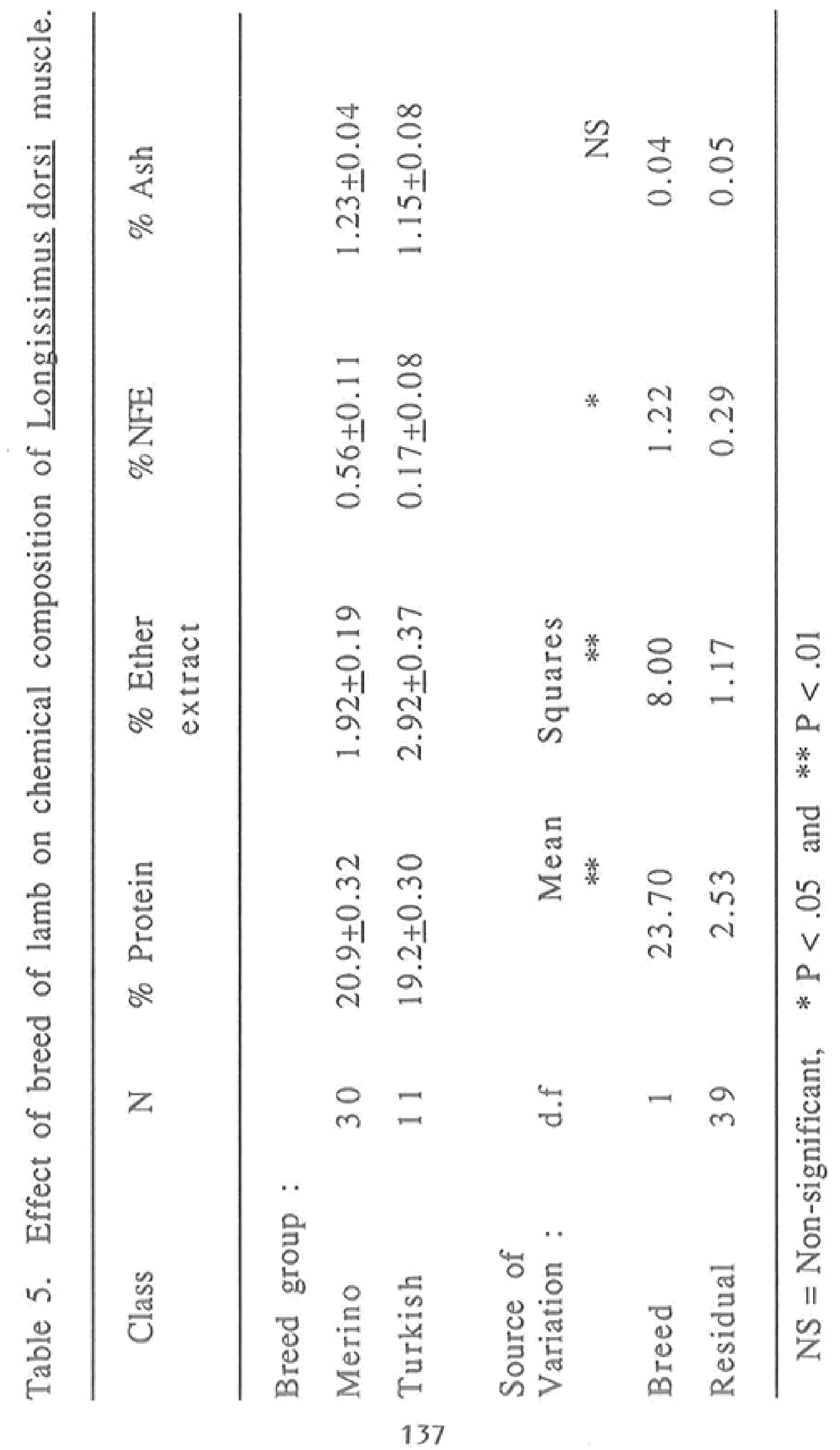




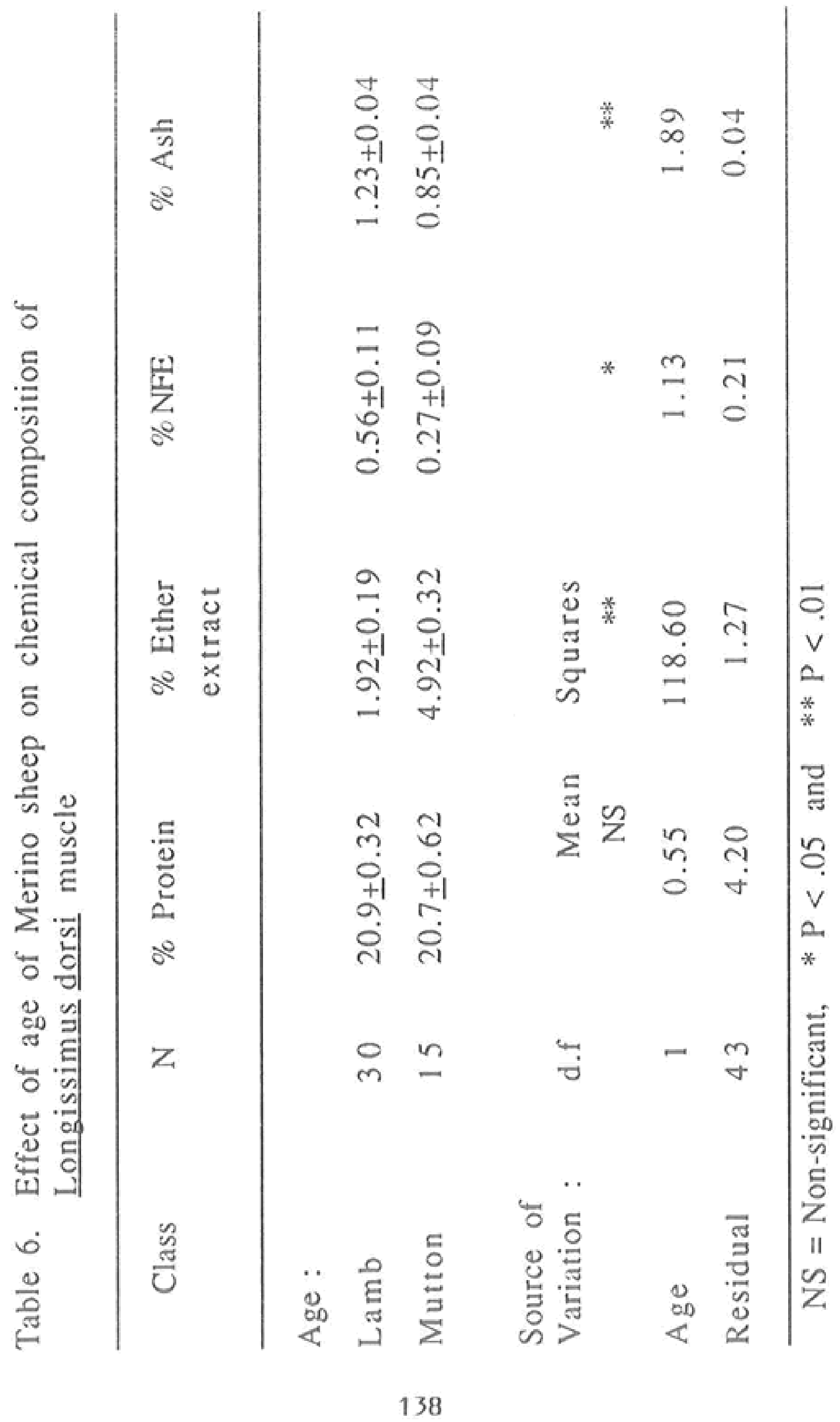


Table 7. Simple, within subclass, cocfficients of correlation (above) among physical and chemical composition parameters.

\% Fat Bone Moisture Protein $\begin{aligned} & \text { Ether } \\ & \text { extract }\end{aligned}$ Ash

Lea

$-0.779$

0.102

0.337

0.239

$-0.37$

0.382

$(.0001)$

(NS) $\quad(0.01)$

(NS) (0.005) (0.004)

Fat

$$
-0.703-0.526
$$

0.317

$\begin{array}{ll}0.492 & -0.431\end{array}$

$\begin{array}{llllll}(.0001) & (.0001) & (0.02) & (.0001) & (.001)\end{array}$

Bone

$\begin{array}{llll}0.452 & -0.231 & -0.360 & 0.251\end{array}$

(.0005)

(NS) (0.006) (NS)

Moisture

$\begin{array}{lll}-0.409 & -0.328 & 0.419\end{array}$

(0.0008) (0.008) (0.0006)

Protein

$\begin{array}{ll}0.537 & -0.647\end{array}$

$(0.0001)(0.0001)$

Ether extract

$-0.543$

(0.0001)

( ) between brackets are levels of significance;

NS $=$ Non-significant. 
lean and $\%$ bone on the other hand, $\quad(r=-0.779$ and -0.703 , resp. and $p<.0001)$. These results indicate that the increase in fat content occurs on the account of both lean and bone proportions.

Among chemical components of the L.d. muscle, the results indicated that the increase in dry matter content is basically due to increasing fat and to a lesser extent to protein contents. The decline in $\%$ ash was accompanied also by an increase in the same two components.

The relationships among physical and chemical parameters are manifested clearly in the cases between : \% fat in rib cut and \% ether extract in L.d. muscle $(\mathrm{r}=0.492, \mathrm{p}<.0001)$ and $\%$ fat and both of $\%$ moisture and $\%$ ash $(\mathrm{r}=-0.526, \mathrm{p}<.0001$ and $\mathrm{r}=-.431$, $\mathrm{p}<.001$, resp.). Percentage of lean in rib cut showed negative relationship with ether extract $(\mathrm{r}=-.371$, $\mathrm{p}<.005)$ and showed also negative and non-significant relationship with, surprisingly, $\%$ protein in L.d. muscle. Reid (1972) obtained higher relationship between carcass protein and dissected lean and between carcass ether extract and dissected fat of lambs. However, Berg and Butterfield (1976) pointed the attention out to the great need for more studies determining carcass composition by physical dissection followed by chemical composition of the dissected tissues to establish the true relationship between the two procedures. 


\section{REFERENCES}

AOAC. 1986. Official Methods of Analysis. 12th Ed. Association of Official Agricultural Chemists, Washington DC.

Berg, R.T. and R.M. Butterfield. 1976. "New Concepts of Cattle Growth". Sydney University Press, Sydney.

Butterfield, R.M. 1988. "New concepts of sheep growth". Griffin Press, Marion Rd., South Australia.

Devendra, C. and J.E. Owen. 1983. Quantitative and qualitative aspects of meat production from goats. World Anim. Rev. 47 : 19 - 29.

McGregor, B.A. 1982. Growth of organ and body components of grazing goats. Proc. Aust. Soc. Anim. Prod. 14:487-490. (Cited by Warmington B.G. and A.H. Kirton. 1990. Genetic and nongenetic influences in growth and carcass traits of goats. Small Rumin. Res. 3:147-165.

Mtenga, L.A. and A.J. Kitly. 1990. Growth performance and carcass characteristics of Tanzanian goats fed chloris gayana hay with different levels of protein supplement. Small Rumin. Res. $3: 1-8$.

Pattie, W.A. and B.J. Restall. 1987. Breeding cashmere in Australian feral goats. Proc. 2nd Int. Cashmere Conf., Lincoln College, Canterbury, New Zealand. pp. 51-62. (Cited by Warmington, B.G. and A.H. Kirton. 1990. Genetic and non- 
genetic influences in growth and carcass traits of goats. Small Rumin. Res. 3:147-165).

Reid, J.T. 1972. Brit. Soc. Anim. Prod. Conf. Paper. (Cited by Berg, R.T. and R.M. Butterfield. 1976. "New Concepts of Cattle Growth". Sydney Univ. Press. Sydney).

SAS User's Guide. 1982. SAS Inst. Inc., Carry, NC.

Thonney, M.L., Taylor St. C.S., Murray, J.I. and T.H. McClelland. 1987. Breed and sex differences in equally mature sheep and goats. 2. Body components at slaughter. Anim. Prod. 45:261276.

Warmington, B.G. and A.H. Kirton. 1990. Genetic and non-genetic influences on growth and carcass traits of goats. Small Rumin. Res. 3:147-165. 
خصائص لخوم سلالات الأغنام واللاعز شائعة الإستهلاك ني

دولة الإمارات العربية المتحدة .

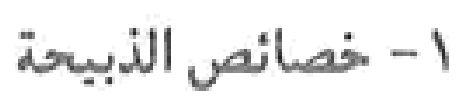

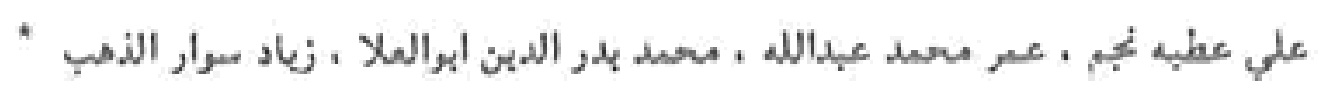

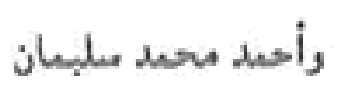

كلية العلوم الزراعبة - جامعة الإمارات العربية المثحدة - العبن - دولة الإمارات العربية المثحدi

* المسلخ الآلي - المين - دولة الإمارات العربية المثهنة

: $20|1|$

أجبريت هذه الدرأسة في المسلغ الآلي بالعين ومـنتبرات كلبة الصلوم الزراعبة بباهعة الإمارات

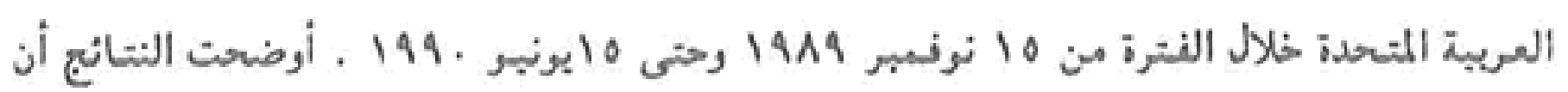

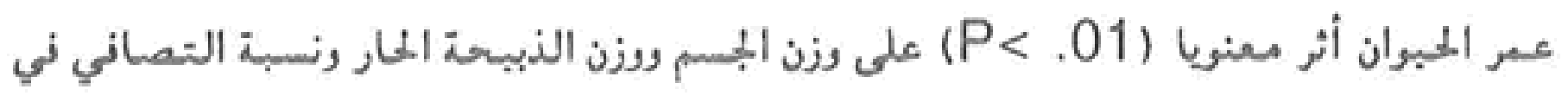

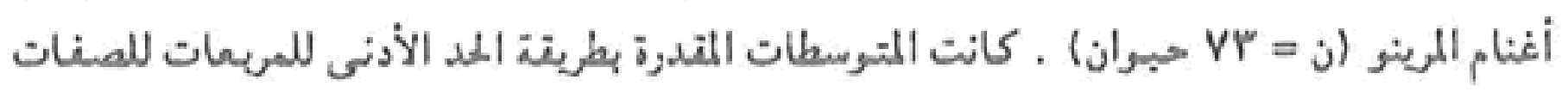

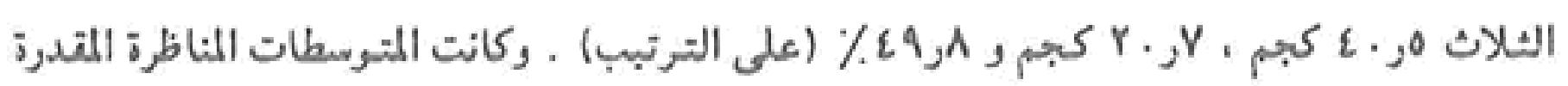

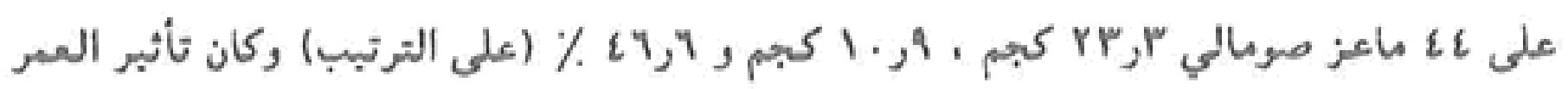
فبها sعنويأ على وزن الذيبحة ونسبة التصافي فتط (P.01)

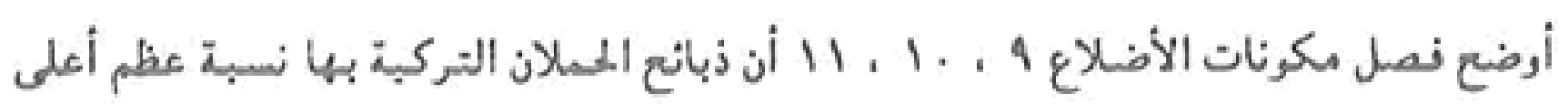

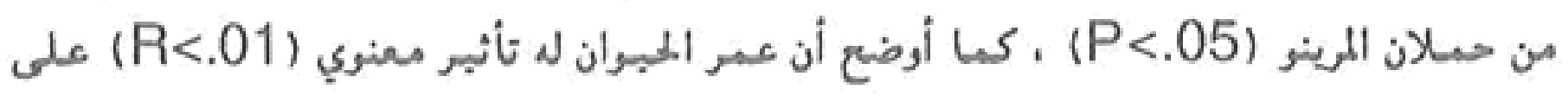
نسب اللهم الأحمر والدهن والعظام وكذلك على سمك طبقة الدهن نوت الضلع التاسع .

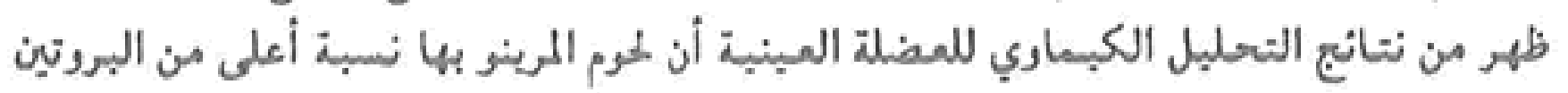

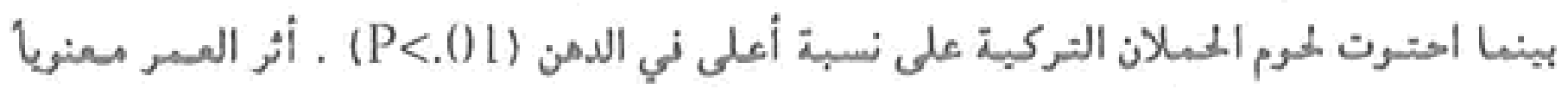

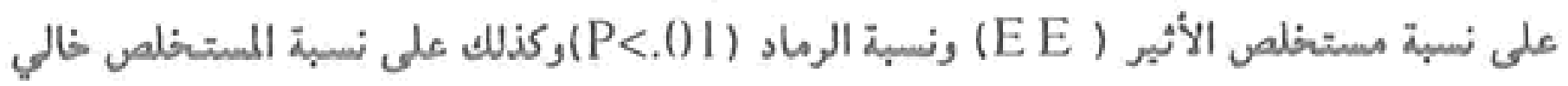

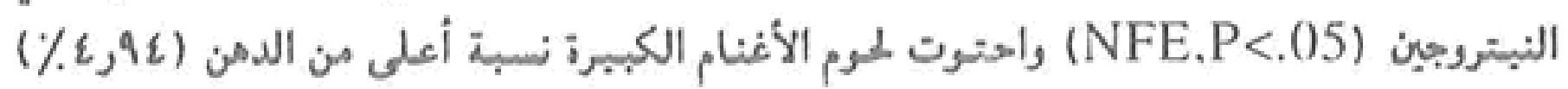

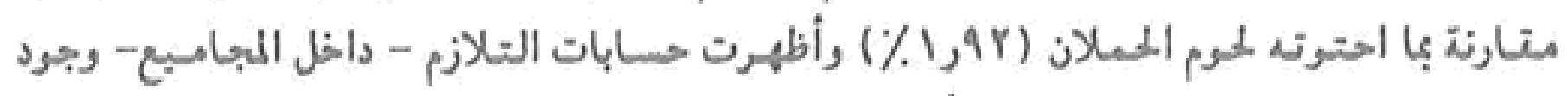

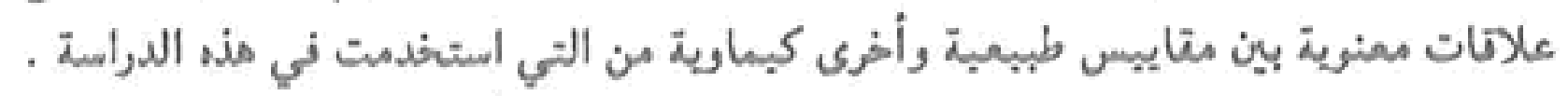
كلمات ملغإهية : سلالات ، خصاتص ، الذبيهة ، ماعز ، أغنام ، دولة الإمارات العربية . 